\title{
Questions, Theory, Darfur, Data
}

\author{
"Imagine ..."
}

"If men define situations as real, they are real in their consequences." These famous words, coined by W. I. Thomas (I928), the classical Chicago School sociologist, have particular weight when mass violence and atrocities are at stake. Politicians, diplomats, military leaders, NGO activists, jurists, journalists, and citizens define such situations. Their definitions codetermine how the world responds to events such as those in Cambodia in the I970s, in Rwanda and the former Yugoslavia in the I990s, or in Darfur in the 2000s. It has often been argued for the case of Rwanda that the United Nations' and the US government's reluctance to call the I994 mass killings genocidal prevented an appropriate response and cost hundreds of thousands of additional lives. It thus matters whether we define mass violence as a form of genocide specifically, as criminal violence generally, or as something else altogether.

Definitions of mass violence as crime, some argue, have advanced fast in the late twentieth and early twenty-first century, an era characterized by a "justice cascade" according to some scholars (Sikkink 20II). But actors may define mass violence differently, for example, as an insurgency or counterinsurgency, a civil war, or a complex humanitarian emergency, and each of these definitions will support a distinct response. In the radical alternative, we may refuse to register the suffering and practice denial (Cohen 200I). In this book I explore the struggles over recognition and over competing definitions of the mass violence that befell the Darfur region of Sudan in the first decade of the 


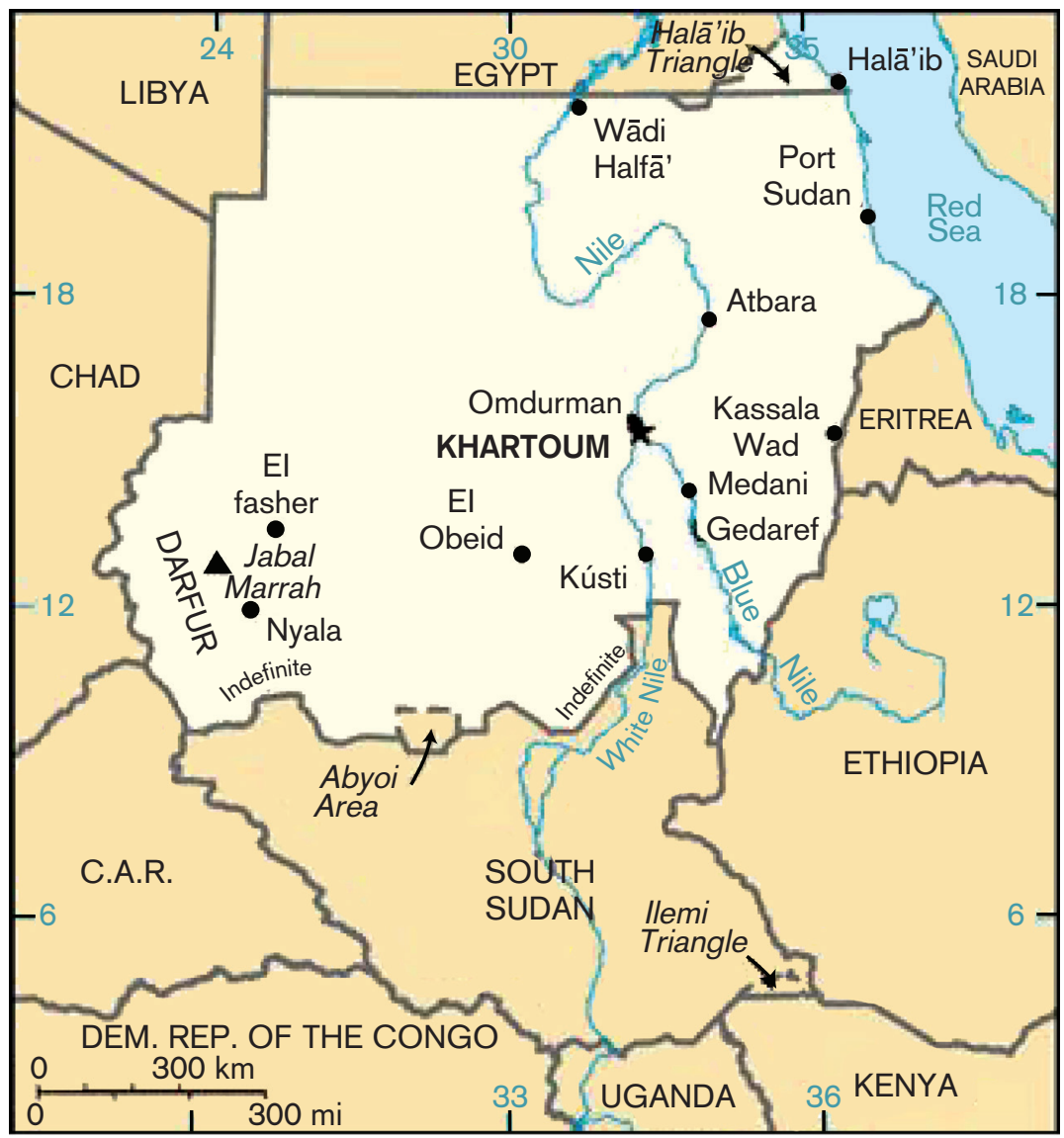

FIGURE I. Darfur within Sudan and neighboring countries.

twenty-first century (see figure I). I focus on the fields of human rights and criminal law, humanitarianism, and diplomacy, as they generate at least partially competing representations of the mass violence, and on the journalistic field and its contribution to the diffusion of competing narratives to a wide public. I invite the reader to accompany me on this journey.

Imagine you enter the light-filled foyer and modern extension of Germany's foreign ministry in Berlin. You then cross an expansive courtyard and finally reach the massive Nazi-era building, survivor of the destructions of the final stages of World War II, and once home to Joseph Goebbels's Ministry of Propaganda. There you learn from the Sudan specialist of the Auswärtige Amt, as the foreign ministry is called 
in Germany, about this country's diplomatic efforts toward advancing peace in Sudan. You listen to skeptical comments regarding the use of penal law, a tool deemed at least partially incompatible with diplomacy. Now envision a lecture room at Georgetown University's Law School in Washington, DC, where you meet a young Amnesty International activist. She tells you vivid tales about her and her organization's efforts to help bring those to (criminal) justice who bear primary responsibility for the suffering of the people of Darfur. Finally, imagine a small conference room in the Geneva operational center of Doctors Without Borders (MSF), where the interviewee, himself witness to horrific suffering in many areas of mass violence, including Darfur, speaks eloquently about impediments that criminal justice interventions create for those who seek to alleviate the pain on the ground and to save lives. $\mathrm{He}$ is especially critical of the work of human rights activists and the International Criminal Court (ICC) with its interventions in Darfur.

You travel beyond Berlin, Washington, and Geneva to London, Dublin, Paris, Frankfurt, Munich, Vienna, New York City, The Hague, and Bern, and finally arrange for a collaborator to visit Nairobi and Johannesburg. You speak with foreign policy makers, workers for international NGOs (INGOs) - both those with rights agendas and those with humanitarian aid orientations, and Africa correspondents of prominent newspapers. You are impressed by many of your interviewees. Most have left the stability of their home countries to instead devote crucial chapters of their lives and careers to responding to catastrophic situations. They have traded comfort for danger and hardship. You encounter intense engagement, profound belief in the mission to which your conversation partners are devoted. And you are exposed to distinct narratives, representations, and knowledge repertoires about what occurred in Darfur. Suggestions of appropriate remedies are aligned with these narratives and they diverge just as profoundly. Significant differences also appear among respondents within the same sector but with different national backgrounds. How, then, do we make sense of the varieties of stories we hear about the same event, each presented with passion and conviction? This book seeks to answer that question.

Imagine further the reader of some 3,400 news reports and opinion pieces about Darfur, all published by leading newspapers in eight Western countries. That reader would encounter amalgams of the narratives we heard in interviews and conversations while traveling to the homes of governments, media organizations, and INGOs. But this reader wants to go further and identify patterns of reporting, hoping to 
find out, for example, which newspapers (or papers from which countries) are how likely to report about the rapes in Darfur or to term the killings genocidal or to cite the ICC and apply a criminal justice frame to the violence-as opposed to a civil war or humanitarian emergency frame. Our reader then convinces the National Science Foundation to support such effort and engages a team of $\mathrm{PhD}$ students to code the content of all of these articles along a systematic set of analytic dimensions. Coders document the place and timing of each article, what it reports, and how.

This is in fact what I did. As I began to analyze the resulting Darfur media data set, fascinating patterns emerged. I realized, for example, that criminal justice actors and their supporters do affect how media report about the Darfur conflict. Applications of the crime frame to the violence in Darfur, as opposed to the civil war or humanitarian emergency frames, have increased substantially in all eight countries at crucial (but not all) intervention points. They did so, for example, after the International Commission of Inquiry on Darfur, established by the UN Security Council, released its report on Darfur on January 25, 2005; when the ICC issued its first arrest warrants-against Ahmed Harun, a Sudanese minister, and Ali Kushayb, a Janjawiid militia leader-on April 27, 2007; and, eventually, when the prosecutor applied for and the court issued an arrest warrant against Omar al-Bashir, the president of Sudan, charging him initially with war crimes and crimes against humanity (March 4, 2009) and ultimately with genocide (July I 2, 20I0).

It would be a grave error to mistake such effects of court activity on the public representation of mass violence as trivial. First, much constructivist research has shown that media foci are not necessarily-and at times not at all-related to events (and institutional responses to them) in the real world. It is thus not to be taken for granted that media will pay attention to actions by the ICC, despite intense efforts by its press office. Second, the fact that categories of criminal law are being applied to the actions of political and military leaders and resulting mass violence is a revolutionary achievement of the twentieth century (Giesen 2004b). Third, variation across countries shows that the type of representation of mass violence is not a matter of course but something to be explained. For example, news media of different countries vary in their willingness to subscribe to the crime frame as an appropriate lens through which to interpret the events in Darfur.

The Darfur media data set similarly shows that media in the eight countries are not evenly willing to refer to the violence in Darfur as 
genocidal. German news reporters are particularly reluctant to use the "G-word," and Irish reports are generally cautious in the use of both the crime and genocide frames. Interviews in these countries show that such caution is not limited to news media. US papers, on the other hand, liberally refer to the violence as criminal and call genocidal the killings, rapes, destruction of livelihood and displacements in Darfur. American editorial writers go even further. They do not shy away from building rhetorical bridges between Darfur and the Holocaust. Nicholas Kristof stands out when he argues in the New York Times: "The Sudanese authorities, much like the Turks in I9I 5 and the Nazis in the I930's, apparently calculated that genocide offered considerable domestic benefits-like the long-term stability to be achieved by a 'final solution' of conflicts between Arabs and non-Arabs-and that the world would not really care very much" (NYT 6/I9/o4, sec. A, p. I7). Elsewhere Kristof asserts: "As in Rwanda and even during the Holocaust, racist ideologies sometimes disguise greed, insecurity and other pathologies. Indeed, one of the genocide's aims is to drive away African tribes to achieve what Hitler called Lebensraum: 'living space' for nomadic Arabs and their camels" (NYT 3/I4/o6, sec. A, p. 27).

By now you have begun to ask: Why such differences? Why do we find an array of affinities, varying by societal field and country, toward applying the crime frame to Darfur and to calling the atrocities genocide? Why do some actors instead prefer to describe the violence as a case of civil war or as a humanitarian emergency? And why do such preferences vary over time?

Answers to such questions matter in scholarly and in policy terms. We know that whether and how we acknowledge and name instances of mass violence, and whom we blame, has consequences for the willingness of the international community to intervene, and to do so either with diplomatic, judicial, humanitarian, or military means. The history of Rwanda is a case in point. US president Bill Clinton later considered as a low point of his presidency his administration's reluctance to name the Rwandan mass killings of I994 "genocide" and to intervene accordingly. ${ }^{\mathrm{T}}$

In the world of scholarship, comparativists, cultural sociologists, and globalization scholars will want to know why global or nationally distinct definitions of a situation of mass violence come to bear. Especially, why do national distinctions become manifest for a globally recognized problem such as Darfur, in which powerful international actors are engaged? Further, sociolegal scholars and criminologists are eager to learn how 
nation- and field-specific leanings interact with the potential of legal proceedings to shape visions of the past and to thus prevent future violence. Finally, human rights scholars, as well as activists, ask what enhances-and what impedes - the unfolding of the "justice cascade," the massive increase in individual criminal accountability for grave human rights offenses in the late twentieth and early twenty-first centuries (Sikkink 20I I).

In the following chapters I introduce the reader to my discoveries about how global actors, national contexts, and distinct fields interact to create at times conflicting social constructions of the reality of aggression and suffering in Darfur. To do so, I engage different interrelated themes, all central to current scholarship and all implicated in these introductory paragraphs: (I) the criminalization of grave human rights violations; (2) the embeddedness of actors in competing fields of criminal justice, diplomacy, and humanitarian aid; (3) the role media play in communicating messages from these fields to a broad public; (4) tensions and interactions between global and national actors; and (5) consequences for the shape that knowledge about atrocities takes and potential effects on civil society and governmental responses. Throughout, I provide much space to let the actors speak, aiming toward an interpretive understanding of their actions. Combining such understanding with an analysis of the conditions their respective fields impose contributes to an explanation of unfolding responses to the mass violence. A few words on each of the central themes are followed by a brief reminder of what occurred in Darfur and by an exposition of the data and methods I put to work.

\section{JUSTICE CASCADE, FIELDS, AND REPRESENTATIONS BETWEEN THE GLOBAL AND THE NATIONAL}

The first theme concerns the long journey from disregard, often denial (Cohen 200I), at times even glorification (Giesen 2004b) of mass violence toward, via cautious steps, its definition as criminal and what political scientist Kathryn Sikkink (20I I) has recently called a "justice cascade," a global fight against grave violations of human rights. This journey has been promoted by problem entrepreneurs whom I shall take seriously in this book-together with their challengers. I thus link a prominent line of scholarship in constructivist criminology, including the by now classical scholarship of Turk (I969), Chambliss (I964), and Gusfield (I967) and more recent contributions (e.g., Jenness 2004), to a new line of work on the criminalization of human rights offenses (Keck and Sikkink I998; 
Sikkink 20II; Neier 20I2). Activists invest great hopes in these trends, and some scholarship supports their hopes. Yet, to judge the potential of new legal strategies, we have to recognize the actors' location within social fields and the challenges they face from competing fields.

The second theme is thus the embeddedness of actors in distinct social fields. I here initially focus on the fields of criminal law and justice (Hagan 2003), humanitarian aid (Krause 20I4; Redfield 20I3; Weissman 20II), and diplomacy (Power 2002; Scheffer 20I 2; K. Smith 20I0). ${ }^{2}$ As I examine conflicts within and between these fields for the case of Darfur, I use the concept of fields liberally, linking elements of field theory as developed by Pierre Bourdieu (1987, 1988, I998) and his followers (Benson 1998, 2006, 2013; Hagan and Levi 2005) with notions of strategic action fields proposed by Neil Fligstein and his collaborators (Fligstein 200I; Fligstein and McAdam 20II). Despite important distinctions, both approaches share basic insights. They sensitize us to the fact that fields are made up of real social actors. These actors pursue specific goals such as justice, humanitarianism, and peace while simultaneously seeking to strengthen their own position within their respective fields. They are also carriers of habitus, a set of relatively fixed dispositions that reflect their trajectories and their position within the field. To achieve their distinct goals, actors have to incorporate into their habitus their field's dominant institutional logic, a notion borrowed from Weberian ideas (Weber 1978) as specified in the work of Luhmann (2004). In criminal law, for example, this means a focus on specific individual actors (as opposed to social structures a sociologist might stress), on a binary logic of guilty versus not guilty (avoiding differentiations of social psychologists), and on those types of evidence that are compatible with procedural requirements of the law (not those deemed relevant by a historian).

To complicate things further, fields are often interlinked and their inhabitants draw on diverse sources of habitus. Fields thus interpenetrate each other. One interviewee, for example, the director of an operational center of a major humanitarian aid agency in Europe, should not be inclined toward criminal justice responses. Yet, trained as a lawyer in the United States, he deviated from many of his humanitarian colleagues in this respect. His position in the organizational field, his educational background, and his national upbringing simultaneously contributed to his distinct knowledge and habitus. Biographical trajectory and field demands may thus not always harmonize. Instead, they often produce a tension that creates room for improvisation. 
Third, as I explore how competing fields and their definitions of reality interact with civil society, I examine their impact on the journalistic field. Very few members of Western societies ever encounter mass violence in places such as Darfur directly. In contrast to other policy areas, most learn about such events only through media messages. Through them they become subject to distant suffering (Boltanski I999). To the degree that policy decisions are informed by public perceptions of social issues, media thus become important social forces that affect whether and how governments will respond to mass violence in distant places. Recent Bourdieuian work on journalism (Bourdieu I998; Benson I998, 2006, 20I4; Benson and Neveu 2005), lines of research that explore the boundaries between the journalistic and the political fields (Mazzoleni and Schulz 1999; Revers 20I4; Strömbeck and Esser 20I4), and culturally inspired work on journalism (Hannerz 2004; Zelizer 1993) provide inspiration for this analysis. In addition, historical and sociological literature contributes theoretical ideas and empirical information on ways in which crime and genocide narratives created in the judicial field are processed in media reports (Pendas 2006; Jardim 20I2; Savelsberg and King 20II).

Fourth, one of the complications of the fields we study is their location in the intersection of the global and the local. A social movement organization may be international, yet be composed of national sections. The International Criminal Court operates at the global level, but its governing body is the Assembly of States, in which those countries that have ratified the Rome Statute are represented. Its lawyers were trained in their home countries. Throughout I shall thus pay close attention to the simultaneous engagement of actors at global and national levels. Should we not expect globally unified representations of an event such as Darfur in which so many international actors are engaged? Globalization theorists such as the World Polity School of John Meyer and his neo-institutionalist followers would suggest exactly that (e.g., Boyle and Meyer I998; Frank, Hironaka, and Schofer 2000). But others insert a note of caution; some in fact thoroughly disagree. They highlight nation-specific social forces, carrier groups, interests, institutions, and cultural sensitivities, rooted in a country's history, through which global themes, representations, narratives, or norms are filtered (Bendix [1949] I974; Gorski 2003; Roth 1987; Rueschemeyer 1973; Kalberg I994, 2014; Savelsberg and King 2005). ${ }^{3}$ And, indeed, empirical work shows 
national particularities in the way Western governments (K. Smith 20IO; Power 2002) and NGO actors (Stroup 20I2) respond to genocide and mass atrocities. More recently, even work inspired by the World Polity School has examined nation-specific patterns in the promulgation (Halliday and Carruthers 2009) and implementation of law, including human rights law (Boyle 2002, on laws against female genital cutting). Yet other scholars write about cosmopolitanism, especially in the realm of human rights (e.g., Levy and Sznaider 20I0). They take the nation level seriously, while insisting that international and global concerns are increasingly incorporated into national ideas, memories, and practices.

Within this complex intersection of overlapping and conflicting fields there emerge cognitive and normative tools and policy responses to situations of mass violence. This book is thus linked to a fifth theme or intellectual tradition: the sociology of knowledge, rooted in classical works of Emile Durkheim and Karl Mannheim. Its tools further contribute to our explorations of how our competing fields, at national and global levels, constitute distinct conditions and interact to produce patterns of collective representations (Durkheim [I9I2] 200I; P. Smith 2008) that are selectively communicated by news media. As I examine such representations, I pay particular attention to four forms they may take: acknowledgment (Cohen 200I), framing (Goffman I986; Benford and Snow 2000), arguments about causation, and bridging strategies (Alexander 2004). The last-named form links contemporary events, still diffuse in the public mind, to past ones for which a clear understanding has emerged. Collective representations then constitute a cultural repertoire of tools (Swidler I986), from which creators of collective memory (Halbwachs I992; Olick I999; Osiel I997; Savelsberg and King 20I I) and cultural trauma (Alexander et al. 2004) will eventually be able to draw.

Understanding these patterns is a crucial precondition for making sense of, explaining, and predicting ways in which civil societies and governments respond to mass atrocities and grave violations of human rights. And such responses affect chances of breaking cycles of violence (Minow 1998, 2002) that have repeatedly tortured humanity throughout its history. These responses will determine if, at the global level, a degree of pacification can be achieved that many societies have arrived at in centuries of modern state formation (Elias I978; Johnson and Monkkonen 1996). 
DARFUR: SCHOLARLY DEFINITIONS

OF THE SITUATION

In addition to myriad activist and journalistic accounts, several academic books about the violent conflict in Darfur have been published (e.g., Flint and de Waal 2008; Hagan and Rymond-Richmond 2008; Mamdani 2009a; Prunier 2007). Reading these books reveals a scholarly consensus that massive violence unfolded, that many people lost their lives, and that two to three million Darfuris were displaced during the first decade of the twenty-first century.

Yet reading social scientific accounts of the mass violence in Darfur quickly reveals fundamental differences and tensions as well. I here briefly describe agreements and disagreements for the example of three (sets of) authors who wrote remarkable books on Darfur. All three occupy distinct locations within the academic field, which should affect the knowledge they contribute. John Hagan and Wenona RymondRichmond wrote Darfur and the Crime of Genocide, published in 2008 by Cambridge University Press. Julie Flint and Alex de Waal updated their Darfur: A New History of a Long War in a new edition published in 2008 by Zed Books in association with the International African Institute, the Royal African Society, and the Social Science Research Council. Finally, Mahmood Mamdani wrote Saviors and Survivors: Darfur, Politics, and the War on Terror, published in 2009 by Doubleday.

While Julie Flint is a journalist, the other authors are scholars. But all differ in sociologically significant ways. Hagan, a former president of the American Society of Criminology, is a professor of sociology and law at Northwestern University and codirector of the Center of Law and Globalization at the American Bar Foundation. RymondRichmond, a former student of Hagan, is on the sociology faculty at the University of Massachusetts at Amherst. De Waal, educated as a social anthropologist, has worked in several prestigious multidisciplinary social science institutions and now teaches at the Fletcher School of International Affairs at Tufts University. One of his book's photographs is of Sheik Hilal Mohamed Abdalla, taken in 1985 by the author himself and attesting to his long-term ethnographic familiarity with the region. The sheik, as those familiar with the history of Darfur know, is the father of Musa Hilal, one of the leading Janjawiid perpetrators. Finally, Mamdani, a political scientist and anthropologist, is a professor at Columbia University. The biographical blurb in his book describes him as "a third-generation East African of Indian descent [who] grew 
up in Kampala, Uganda, and received his Ph.D. from Harvard in I974" (Mamdani 2009a:399). Even these brief sketches reveal that our authors occupy distinct places in the field of academia. There they compete for recognition, but they do so beyond the world of scholarship as well. The publication of two of the three books by at least partially commercial presses attests to the latter. So does the engagement of de Waal in policy and consulting positions, for example, as a senior advisor to the African Union High Level Implementation Panel for Sudan, a role in which he served from 2009 to 20 I I. Not surprisingly, my interviews indicate that de Waal is by far the best known of these authors among journalists, policy makers, and NGO workers.

The position of these scholars in the academic field should affect which ideas they find acceptable or even thinkable, a link Pierre Bourdieu famously documented in his work Homo Academicus. Bourdieu (I988) also argues convincingly that not just the position of scholars in the academic field but also the relationship of an academic field to other societal fields affects knowledge. One of Bourdieu's chapter headings cites Kant's reference to the "conflict of the faculties," suggesting that closeness to the government places faculties on the right side of the political spectrum. But closeness to other institutional fields and movements also matters. The field of international criminal law and justice fares prominently in our case. Hagan and Rymond-Richmond are oriented toward it. So does the anti-postcolonialism movement, with which Mamdani is allied. And finally, de Waal is linked to the field of international governmental organizations, especially the African Union. Each of these fields entails specific sets of knowledge, and such knowledge is likely to color the depiction of Darfur by those affiliated with it. I thus suggest that we briefly consider events in Darfur by taking into account the overlaps and tensions between these books, written from distinct locations and covering themes of suffering and victimhood, responsible actors, origins, causes, and frames through which the violence is interpreted and, finally, policy preferences are formed.

All three books agree that great suffering has befallen the people in the "land of the Fur," to use the English translation of Darfur, that western part of Sudan, once a powerful Sultanate, incorporated into Sudan under British colonial rule and divided into three states by the Sudanese government in I994. Population was estimated at seven million in the early stages of the mass violence in 2004. There is also little disagreement that violence dates back at least to the I980s; that it initially peaked in the "First Arab-Fur War" of 1987-I989 (Flint and de 
Waal 2008:277) and in the 1995-1999 Arab-Masalit conflict; but that the most destructive wave of violence occurred in 2003 and 2004. In this our three authors concur with almost all who have written about Darfur. People have been killed, raped, and displaced, their livelihood destroyed. Yet differences appear when we examine the victim count and the details into which the authors go to depict the suffering in Darfur.

Hagan and Rymond-Richmond (2008) base their account on an analysis of the qualitative and quantitative materials entailed in the Atrocities Documentation Survey (ADS), a massive data collection initiated by the US Department of State under then-secretary of state Colin Powell. The survey was conducted in summer 2004 among more than one thousand Darfuris who had crossed the border into neighboring Chad to seek protection in newly established refugee camps. These authors pay minute attention to the death toll and to the extent of other forms of victimization. They quote generously from qualitative interview materials, sharing with the reader horrendous stories that refugees told about their experience of mass killings, destruction, and rape campaigns: "First vehicles attacked the village. After one hour, planes came and bombed; after this military came on camels and horses and began shooting at random. They cut open the stomachs of pregnant women and split the throats of male fetuses. Bombs from airplanes killed a lot of animals and people. The military took women away. The village was burned and destroyed. They shot at anyone: man, woman, or child" (Hagan and Rymond-Richmond 2008:7-8).4

Hagan and his collaborators also seek to establish numerical estimates. Critiquing public health researchers who focus on mortality resulting from malnutrition and disease in displaced-person and refugee camps, they add survey-based estimates of deaths that are directly attributable to the violence. Hagan with Alberto Palloni, a past president of the Population Association of America, estimates a death toll of 350,000 (Hagan and Palloni 2005).5

Flint and de Waal (2008) do not engage in the accounting of victimization à la Hagan and Rymond-Richmond. Yet they do cite social movements, such as Save Darfur, and these movements' estimates of a death toll of 400,000 (Flint and de Waal 2008:I 86). Their text further takes pains to display the horrific violence, at times based on ICC accounts of specific events:

Starting in August 2003, according to the ICC, Security [Forces] and militias worked hand-in-glove to clear a swath of Wadi Saleh. ... A fertile area, long coveted by Arabs of Chadian origin, Wadi Saleh was now crowded with tens of thousands of displaced Fur and Masalit. By the end of the year, thirty-two 
villages and hamlets along its tributary, Wadi Debarei, had been burned and displaced villagers had converged on the market town of Deleig. Over a period of weeks, army and Janjawiid captured and killed $7_{2}$ people in the Deleig area. Some had their throats cut and their bodies thrown in the stagnant pool of a seasonal river just south of the town. (Flint and de Waal 2008:129-30)

The authors also describe in some detail the attacks on villages by Antonov planes of the Sudanese Armed Forces (SAF), often followed by Janjawiid raids that completed the destruction and killings and drove away any remaining residents.

Mamdani's account (2009a) of victimization differs substantially. He does not provide analyses of fatalities himself, and he abstains from confronting the reader with detailed descriptions of the brutalities committed on the ground. He also keeps his distance from any attempt to account for the number of victims. Instead he reviews, at times ironically, the "numbers debate" (Mamdani 2009a:25). He displays different and shifting death estimates that range from the tens of thousands up to a half million. He interprets the divergences as expressions of political strategizing by "human rights entrepreneurs" (28), including John Hagan ("most authoritative" [28]); Eric Reeves, an English professor at Smith College and frequent commentator on Darfur ("most prolific" [28]); and Nikolas Kristof from the New York Times ("another indefatigable crusader" [29]). While not providing his own estimate, he appears to sympathize with the doubts about high-end estimates expressed in a 2006 study by the US General Accounting Office. If indeed the struggle over numbers is part of a political game, as Mamdani suggests, he certainly is one player in this game.

Just as the tales of victimization and suffering differ between the three (sets of) authors, placed in different locales within the academic space, so does their depiction of responsible actors. Hagan and Rymond-Richmond (2008) see as aggressors the Sudanese government, the SAF, and the Janjawiid, the infamous Arab militias that received massive material and symbolic support from the Sudanese government. These two sociologist-criminologists go further, though. They reconstruct the chain of command, and-based on ADS reports-identify specific individuals as responsible for the mass violence, including those who are now indicted by the ICC. Both Flint and de Waal (2008) and Mamdani (2009a) attribute responsibility differently. To be sure, they never exempt the SAF or the Janjawiid from charges of gross atrocities. In fact, they attribute direct responsibility to some of the same actors identified in Hagan and Rymond-Richmond, such as the former 
minister Ahmed Harun (Hagan and Rymond-Richmond 2008:123, I33) and Janjawiid leaders Ali Kushayb (130) and Musa Hilal (35ff., I 25). Yet the attribution of responsibility by Mamdani and Flint and de Waal is more diffuse. Flint and de Waal (2008) spell out atrocious attacks by rebel forces against Arab groups (135), and they examine the roles that outside actors such as Libya's Gaddafi (47) and Chad's Idriss Déby (27) played in the buildup of violence before it escalated to catastrophic levels in 2003. Mamdani (2009a) also does not deny the agency of the Sudanese state and the militias that drive what he labels "counter-insurgency" (5), but he highlights more clearly the violence committed by insurgents themselves. In fact, he attributes victim status to Arab tribes that are often defined as a crucial source of aggression. To him the rebels were recruited from "the tribes with land who sought to keep out landless or land-poor ["Arab"] tribes fleeing the advancing drought and desert" (4).

These and other differences between the three sets of authors are depicted in table I. Clearly, distinct identifications of victimization and responsible actors correspond with further differences along a set of analytic dimensions that prove crucial throughout this book: time frames, the attribution of causes, and the framing of the violence. We shall see how representations of the mass violence in Darfur shift along these dimensions depending on the sector in which they were produced and, over time, under the influence of judicial interventions.

Considering the time frames, always crucial in the interpretation of mass violence, ${ }^{6}$ Hagan and Rymond-Richmond decidedly focus on recent events and actions. They apply to Darfur an "endogenous conflict theory" that sees ethnic violence as the product of shorter-term dynamics initiated by concrete state actors to whom societal groups responded. Flint and de Waal instead situate the violence in a longerterm history of conflict among the groups populating Darfur. They inform the reader, for example, of troubles that government authorities had with the "camel-herding Abbala Rizeigat" Arabs, back in "the time of the Sultans," and of long-term desertification resulting from droughts and associated struggles for resources they caused already in the I980s (Flint and de Waal 2008:40).7 Mamdani (2009a) also reaches far back into history, taking as his point of departure the colonial era, especially the British colonial administration's effort at "retribalizing Darfur" (I $52 \mathrm{ff}$ ) and "marginalizing" ( $163 \mathrm{ff}$ ) the region. He interprets both strategies as crucial sources of the violence that was to plague the region in subsequent decades and into the present. 
TABLE I. ANALYTIC DIMENSIONS OF THE DARFUR CONFLICT AND THEIR USE BY HOLDERS OF DIFFERENT POSITIONS IN THE ACADEMIC FIELD

\begin{tabular}{llll}
\hline \multirow{2}{*}{$\begin{array}{l}\text { Analytic } \\
\text { Dimension }\end{array}$} & $\begin{array}{l}\text { Hagan and Rymond- } \\
\text { Richmond (2008) }\end{array}$ & $\begin{array}{l}\text { Flint and de } \\
\text { Waal (2008) }\end{array}$ & Mamdani (2009) \\
\hline $\begin{array}{l}\text { Suffering/ } \\
\text { victimization }\end{array}$ & $\begin{array}{l}\text { graphic accounts } \\
\text { high numbers }\end{array}$ & $\begin{array}{l}\text { graphic accounts } \\
\text { high numbers }\end{array}$ & $\begin{array}{l}\text { no depictions } \\
\text { ironizing "numbers } \\
\text { game” }\end{array}$ \\
$\begin{array}{l}\text { Responsible } \\
\text { actors }\end{array}$ & $\begin{array}{l}\text { GoS, SAF, Janjawiid, } \\
\text { specific individuals }\end{array}$ & $\begin{array}{l}\text { GoS, SAF, Janjawiid, } \\
\text { rebels, outside forces } \\
\text { (Libya, Chad) }\end{array}$ & $\begin{array}{l}\text { GoS, SAF, Janjawiid, } \\
\text { rebels (against } \\
\text { impoverished Arab } \\
\text { groups) }\end{array}$ \\
Origins/time & $\begin{array}{l}\text { Short-term, } \\
\text { 2003- }\end{array}$ & $\begin{array}{l}\text { Long-term, } \\
\text { Drought of 1980s } \\
\text { Complex historical, } \\
\text { cross-national }\end{array}$ & $\begin{array}{l}\text { Colonialism } \\
\text { History of } \\
\text { colonialism }\end{array}$ \\
Causes & $\begin{array}{l}\text { Ethnopolitical } \\
\text { entrepreneurs and } \\
\text { processes }\end{array}$ & $\begin{array}{l}\text { War (of total } \\
\text { Crime, genocide }\end{array}$ & $\begin{array}{l}\text { Neocolonial, } \\
\text { counterinsurgency } \\
\text { Negotion) }\end{array}$ \\
Frame & Criminal justice & Negotiations & Negotions \\
Policy & & &
\end{tabular}

"Government of Sudan

Consider, finally, differences the authors apply in their accounts of causes, interpretive frames, and associated policy conclusions. Hagan and Rymond-Richmond (2008) develop a "critical collective framing approach" in which collective action generates a "Sudanese genocidal state as an endogenous system" (I63). Crucial in this process are "ethno-political entrepreneurs" who cultivate fear and disrespect, manipulate racial symbols and identities, and develop "crisis scripts" and apply them to conflicts. In this context, demonizing and supremacist ideologies intensify divisions between Arab and black African groups. They stimulate the use of racial epithets that create a sense of collective effervescence (Durkheim) and feed "collective fury." The final outcome is genocidal violence. The frame Hagan and Rymond-Richmond apply to interpret the violence in Darfur is one of crime, specifically genocide. ${ }^{8}$ It supports a criminal justice response to the violence in Darfur.

Flint and de Waal (2008) differ decisively from Hagan and RymondRichmond's “endogenous” approach. Drawing on their cultural capital, 
a deep familiarity with the history and ethnography of Darfur, they elaborate on complex historical and cross-national processes that contributed to the events of 2003 . Theirs is best characterized as a war frame, specified as "a war of total destruction, 2003-04" (I I6), to cite the title of one of their chapters. Policy conclusions cautiously point toward peace negotiations: "When the political alignments for a negotiated peace recur-which could be a few months' hence or, more likely, many years into the future-the players, the issues, the context, and the solutions could all be different" (388).

Mamdani (2009a) takes a distinct position regarding causes, frames, and policy conclusions. He argues that the roots of the violence in Darfur lie in the history of colonialism and that reactions to the conflict are to be explained by the postcolonial interests of Northern powers. His focus is on "politics of violence, whose sources include both a state-connected counterinsurgency and an organized insurgency" (I 45). 9 Mamdani thus applies an insurgency and counterinsurgency frame, which itself is embedded in a neocolonial frame. His policy conclusions are guided by the insight that "anyone wanting to end the spiraling violence would have to bring about power sharing at the state level and resource sharing at the community level, land being the key resource" (I46). Neither criminal law nor humanitarian intervention, in his view, can enhance these objectives. A settlement is to be achieved via negotiation.

Three (sets of) authors, each with specific locations in the academic field and in relation to other societal fields, provide-despite overlaps-quite distinct representations of the mass violence in Darfur along the dimensions of victimization and suffering, responsible actors, time frame, causes, interpretive frames, and policy conclusions.

\section{IN SEARCH OF ANSWERS: COLLECTING AND}

\section{ANALYZING DATA}

If even scholarship defines the events of Darfur in conflicting ways, then disagreements across distinct societal fields are to be expected. The questions posed above reemerge with particular urgency: How and why does knowledge about Darfur vary across societal fields and over time? Why do we find affinities, varying not only by societal field but also-overlapping with fields-by country, toward applying the crime frame to Darfur and to calling the atrocities genocide? Why do some actors instead prefer to describe the violence as a case of civil war, insurgency and counterinsurgency, or as a humanitarian emergency? Again, 
to answer these questions, I conducted systematic, semistructured interviews, supplemented by many conversations and use of an observational method, and a large-scale content analysis of media reports from eight countries. Before addressing the nuts and bolts of my methods of data collection, one methodological clarification is in order.

\section{Beyond "Methodological Nationalism," "Cosmopolitanism," and "Universalism": Toward Empirical Investigation}

I collected data at the levels of individual media reports, even statements within reports; international organizations; national institutions such as foreign ministries; newspapers; and national sections of international NGOs (INGOs). By prominently including national institutions as units of data collection, however, I do not subscribe to "methodological nationalism" (Beck and Sznaider 2006). Instead, gathering data at the national level reveals information about the intersection of global, national, and local forces. An interview with the Africa correspondent of a German newspaper provides a telling example:

In Nairobi [one of the few central bases of most Western Africa correspondents] things are rather informal. There is not a sense of competition. So you sit down with colleagues to learn from others who have just been to an area what things look like out there. There is quite a lively exchange of experiences and information - and that certainly also leads to some kind of opinion formation.... Often that is not possible in Africa in any other way. As a single person one cannot ... charter a plane.... The trip to North East Congo included journalists from the US, UK, Switzerland, and Germany.... [Also,] there was this foreign correspondents' club. There I met Canadian colleagues, Zimbabwean colleges, etc. (author's translation)

The interview from which this quotation is taken tells us how a German journalist, working for a German paper in a specific locale in an African country, is simultaneously embedded in a global network of correspondents and NGO workers from diverse national contexts. It illustrates one way in which the national and the global are intimately intertwined in the representation of events, including mass violence.

What I find in the world of journalism applies in the political sphere and civil society as well. There, human rights, as a new principle of legitimacy, have come to challenge the notion of national sovereignty and advanced a move toward cosmopolitanism-that is, an incorporation of foreign and distant suffering (Boltanski r999) into local and national concerns-famously explored by Daniel Levy and Natan Sznaider (20I0) 
and Alejandro Baer (20II). Three forces are at play. One is the weakening capacity of nation-states to shape representations of past and current events; instead, local groups and competing affiliations promote a fragmentation of representations. A second is the growing weight of media and communication institutions as producers of representations: distant events create local resonance and identification through the globalization of media images and communication technologies. ${ }^{\text {Io }}$

A third force toward the emergence of cosmopolitanism, one that moves to center stage in the following chapters, is the law. Again I agree with Levy and Sznaider (2010) that "recent trials related to human rights abuses are an important locus for the production of cosmopolitan ideals and their criticism" (I9). More specifically, the post-Cold War era advanced the cosmopolitanization of human rights regimes through a substantial number of domestic human rights trials and the incorporation of international law into domestic jurisdictions (internalization of human rights norms by states). Another indication is the creation of the International Criminal Court with its complementarity principle, securing states' rights to prosecute human rights perpetrators as long as they are willing and able to do so. Global norms thereby become incorporated into national legal institutions.

I here tackle as an empirical question the debate between proponents of methodological nationalism versus universalism versus cosmopolitanism. Based on quantitative and qualitative data on the case of Darfur, I examine the degree to which different types of countries actually incorporate international human rights concerns into their legitimacy basis; the degree to which global legal interventions produce narratives to lay the groundwork for collective memory across countries; and the degree to which these representations are filtered through a particular judicial logic and colored by political constraints under which law operates, especially international law. While broad statements that sanctify the national, the global, or the cosmopolitan may neatly align with "invisible colleges," I place myself between those positions. Again, through systematic collection of data, I examine degrees to which representations of ongoing atrocities are inspired by national forces, universal standards, and cosmopolitan sensitivities.

\section{Why These Eight Western Countries?}

Considered in this book are two North American and six European countries: Canada and the United States on the western side of the 
Atlantic, and Austria, France, Germany, Ireland, the United Kingdom, and Switzerland on the eastern side. The focus on Western countries, all democracies with capitalist economies, warrants justification. Clearly, perceptions and representations from other parts of the world matter. Representations of Darfur in China, Russia, and Arab and African countries differ substantially from those in the West, and they have affected responses of the international community. And yet Western countries are a research subject in their own right. They are crucial players on the world stage. From a methodological point of view, limiting the argument to countries that are similar in basic respects (democracy, capitalism, and wealth) has a major analytic benefit: it reduces variation and thus allows for a controlled comparison along a set of crucial variables.

The set of countries selected for this study includes three permanent members of the UN Security Council (France, UK, US); large countries such as the United States and Germany and small ones such as Austria, Ireland, and Switzerland; countries with varying identities vis-à-vis mass atrocities and genocide, from that of a liberator (US) to that of a perpetrator nation (Germany); countries with colonial involvement in Sudan (UK) or in neighboring countries such as Chad (France), or a lack thereof; countries tightly woven into alliances (France, Germany) to ones that are relatively neutral (Austria and Switzerland); and finally countries in which one of three languages dominates: French, English, or German. It should not be denied that the researcher's ability to read and speak these languages was a pragmatic consideration that supported this selection.

\section{Sources of Data}

Several key sources of data helped in the exploration of representations of Darfur and changes in them over time, especially in relation to judicial interventions: a set of systematic, semistructured interviews with central contributors to those representations; many individual conversations and observations of meetings of key players; a detailed content analysis of news media; and an analysis of documents produced by, among others, foreign ministries and NGOs.

\section{Interviews and Observational Method}

Between November 20I I and November 20I 2 I traveled across North America and Europe to conduct semistructured interviews with Africa correspondents, NGO specialists, and Sudan experts in foreign 
ministries. I had selected one rights-oriented NGO, Amnesty International, and one humanitarian aid-oriented NGO, Médecins Sans Frontières (MSF, or Doctors Without Borders). I also selected two prominent newspapers, one left-liberal, the other conservative or center-right, from each country. Most of the interviews lasted between sixty and eighty minutes, with a few as short as a half an hour or as long as

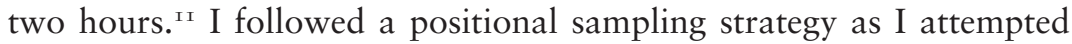
to include at least one Darfur specialist from each of the five organizations in each of the eight countries (thirty-eight country-organizations). I was able to secure forty-two interviews, covering seven foreign ministries, twelve newspapers, and thirteen national divisions of NGOs. Consent was secured from each interviewee in line with the approval by the Institutional Review Board of the University of Minnesota. The interviews were audio-recorded and transcribed. No interviewee is referred to by name in this book. Specific positions of interviewees are explicated only where an appropriate understanding necessitates doing so. In some cases, a respondent's gender ascription may be changed to further disguise his or her identity. After I had collected these European and North American interviews, Wahutu Siguru, a doctoral advisee and collaborator, traveled to Nairobi, in his native Kenya, and to Johannesburg, South Africa, and, following an identical methodology and guideline, conducted interviews with African journalists who had written about Darfur.

Interviews with NGO specialists and Sudan experts in foreign ministries served to explore features of societal fields that contribute to the formation of knowledge about Darfur and with which journalists interact. Interviews with Africa correspondents who contributed a substantial number of articles to the newspapers we analyzed allowed for triangulation: to examine whether positions expressed in specific media confirm or differ from positions their journalists take in interviews. The degree to which they differ tells us something about the independent impact of the media organization for which a journalist works, including its editorial process. All interviews, finally, served to explore the actors' habitus, shaped by their position in the field and their field's position vis-à-vis other fields. Interviews also tell us about the actors' biographic trajectories, their social and economic backgrounds, and the career through which they arrived at their respective positions-factors that also contribute to shaping their habitus.

The structure of the interviews was closely aligned with my thematic concerns. After inquiring about the interviewees' background 
(education, relevant socialization experiences, career path, and work context), I asked about perceptions of victimization, actors responsible for the violence, and causes of the conflict; appropriate frames of interpretation, policy goals, and strategies (and potential conflicts between them) and institutions to execute them (with a special emphasis on the pursuit of justice and the ICC); positions of the interviewees' organization and their nation's government; the role of historical experience; and sources of information (see appendix B for interview guidelines).

In addition to the formal interviews, numerous informal conversations with a diverse array of actors provided insights into the representation of Darfur. I visited with conversation partners in their offices, in coffee shops, and in the context of two conferences. They included European scholars specializing in Sudan; Sudanese informants, specifically anthropologists, journalists, and opposition politicians from Sudan; two US foreign policy makers (ambassadors); other journalists; lawyers from the International Criminal Court; the director of a genocide memorial museum; and Darfur activists. The conferences included a January 20I I symposium titled "War Crimes Journalism" at the Vassar Institute in The Hague, and a summer $20 \mathrm{I} 2$ conference, "Discourses on Darfur," at the Rockefeller Bellagio Center. ${ }^{12}$ I conducted two additional formal interviews with a member of the governing board of one of the Darfur rebel movements and with a Sudan expert of the foreign ministry of a ninth country.

\section{Newspaper Articles and Commentaries}

A detailed international comparison of the changing representations of Darfur can be gained from a fine-grained analysis of news media reports. Together with a group of graduate students, I conducted a content analysis of 3,387 newspaper articles, editorials, and op-ed pieces from the eight countries-a massive undertaking. Following an intense week of training, six coders spent several months laboring individually while regularly joining in group sessions to assure continued agreement regarding the meaning of coding categories.

There are good reasons for such investment. News media, after all, continuously bring the reality of atrocities and grave human rights violations into the homes of people around the world. In fact, media are usually people's only source of knowledge about ongoing atrocities in distant lands. We may argue, with Bourdieu, that media power is "power to consecrate," to name an event, person, or idea worthy 
of further consideration (Benson 1998). Media reports affect ways in which societies think about events, especially those in distant lands, too remote for personal observation.

In addition, media are also indicators of collective knowledge repertoires and processes. Scholarship has documented, and my interviews with Africa correspondents confirm, that journalistic reports and commentaries are the outcome of complex collective action among actors within and outside the media field. Media reports thus constitute collective representations-supra-individual ideas, scripts, beliefs, values, or cognitive and normative images-to which Emile Durkheim ([I9I2] 200I) alerted us long ago in his work on the elementary forms of religious life.

Prominent newspapers are not the only media that communicate news from abroad. In France, for example, beginning in the I960s and I970s, the dominant role that Le Monde and Le Figaro, the most prestigious liberal and conservative newspapers, respectively (and part of our sample), played in the formation of public and elite opinion has been passed on to the television (Bourdieu I998). The same can be said for these newspapers' equivalents in other countries. Simultaneously, however, the weight of television ensures that what appears prominently on TV will almost always make its way into prestigious newspapers. A newspaper analysis is thus unlikely to miss themes that are prominently displayed on television. The same can be said for electronic communication. My interviews reveal that journalists are very much attuned to the Internet and, in their work, draw on information it provides.

As newspaper analysis is thus generally a useful tool, it is especially advantageous to focus on prestigious papers in the current context. ${ }^{\mathrm{I3}}$ Not only are these papers more likely than others to cover foreign news, but their content is hardly ignored by policy makers. Further, in countries such as the United States, the nationally most prominent papers reach far beyond their own readership. Regional and local newspapers across the country, lacking resources to investigate beyond the local or state levels, frequently reprint articles on foreign policy themes from papers such as the New York Times.

I therefore present a comparative and comprehensive exploration of representations of the mass violence in Darfur by examining reporting and commentary in the eight countries' most prestigious daily newspapers with national or supraregional distributions. In what follows, the selection of newspapers, the time periods covered, the sampling and coding strategies, the selection of coders, and issues of intercoder reliability are addressed (see table 2 ). 
TABLE 2. NUMBER OF MEDIA DOCUMENTS (ARTICLES AND OPINION PIECES) CODED, BY NEWSPAPER AND COUNTRY

\begin{tabular}{|c|c|c|c|c|c|}
\hline \multicolumn{6}{|c|}{ Number of media documents (and opinion pieces) } \\
\hline Countries & Conservative & Total & Left-liberal & Total & $\begin{array}{l}\text { Country } \\
\text { total }\end{array}$ \\
\hline Austria & Die Presse & $137(22)$ & $\begin{array}{l}\text { Der } \\
\text { Standard }\end{array}$ & $103(20)$ & $240(42)$ \\
\hline Canada & Toronto Sun & $120(22)$ & $\begin{array}{l}\text { Globe \& } \\
\text { Mail }\end{array}$ & $213(36)$ & $333(58)$ \\
\hline France & Le Figaro & $162(19)$ & Le Monde & $341(31)$ & $503(50)$ \\
\hline Germany & $F A Z$ & $326(34)$ & $S Z$ & $420(68)$ & $746(102)$ \\
\hline Ireland & \multicolumn{4}{|c|}{ Irish Times" $242(35)$} & \\
\hline Switzerland & \multicolumn{4}{|c|}{ Neue Zürcher Zeitung* 209 (5) } & \\
\hline United & London & & & & \\
\hline Kingdom & Times & $197(50)$ & Guardian & $215(45)$ & $412(95)$ \\
\hline $\begin{array}{l}\text { United } \\
\text { States }\end{array}$ & WSJ & $171(43)$ & NY Times & $531(107)$ & $702(150)$ \\
\hline
\end{tabular}

NOTE: WSJ = Wall Street Journal; FAZ = Frankfurter Allgemeine Zeitung; SZ = Süddeutsche Zeitung *Not placed in the left-right typology as it is the only paper in this country with substantial foreign news reporting.

I. Selection of newspapers. One conservative-leaning and one centerleft-leaning newspaper from each of six of the eight countries was selected for analysis, based on reputation and readership numbers. The exceptions are Ireland and Switzerland, where only one paper regularly covers international news. In total, fourteen papers were selected. Table 2 lists the newspapers and details the total number of articles as well as the subset of opinion pieces coded for each.

2. Time periods. Articles from these papers, published between January I, 2003 (the beginning of the period of massive violence), and May 30,2010 (the end of the bulk of our coding work), underwent content analysis. While tensions in the Darfur region developed over several decades, most of the extreme violence occurred during this period. (For an account of the most recent intensifications of violence, see the postscript to this book.) To examine the effect of judicial and quasi-judicial interventions on representations of the violence, I conceptualize the time frame as broken into nine periods. The eight dates below, following the February 2003 rebel attack and the subsequent massive repression by 
the Sudanese military in conjunction with the Janjawiid, separate these periods:

September I 8, 2004: UN Resolution I 564 establishes an International Commission of Inquiry on Darfur.

January 25, 2005: the commission delivers its report to General Secretary Kofi Annan.

March 3I, 2005: the UN Security Council (UNSC) refers the Darfur case to the ICC.

February 27, 2007: the ICC prosecutor applies for an arrest warrant against two midlevel actors for crimes against humanity and war crimes.

April 27, 2007: the ICC issues a warrant for the arrest of both actors for war crimes and crimes against humanity (publicized on May 2, 2007).

July I4, 2008: the ICC prosecutor applies for an arrest warrant against Sudanese president Omar al-Bashir for crimes against humanity, war crimes, and genocide.

March 4, 2009: the ICC issues an arrest warrant against President al-Bashir for crimes against humanity and war crimes (to be supplemented, on July I2, 20I0, with genocide charges).

May I 8, 2009: Bahr Idriss Abu Garda, a rebel leader who had previously been summoned to appear before the ICC under seal, makes his initial appearance before the court.

3. Sampling strategy. Newspaper articles, editorials, and op-ed pieces from each of the fourteen papers were selected using a stratified random sampling strategy. When possible, we utilized the newspaper's online archives of print articles. Online archives were made available by Der Standard, Die Presse, the Süddeutsche Zeitung, and the Toronto Sun. Where online archives of print articles were not available, searches were performed in both LexisNexis and ProQuest Newsstand. The Wall Street Journal was obtained from ProQuest Newsstand, as it was not available through LexisNexis; all other papers were accessed through Lexis Nexis. ${ }^{\text {I4 }}$ Only for the Neue Zürcher Zeitung did we have to rely on the online archive, not knowing whether all articles coded in fact appeared in print. While there is little reason to believe that this difference significantly affects results for the Swiss paper, and while I triangulate these findings via an interview with its most senior correspondent, I cautiously interpret patterns for this paper. 
My coding team identified all articles in the fourteen papers written during the period of interest and containing the search term "Darfur." I5 We included all articles and opinion pieces except letters to the editor. We excluded articles that mentioned Darfur but that, upon closer review, did not pertain to the conflict in Darfur. From all relevant documents, we selected every other article for most time periods and every sixth article for two lengthy time periods that passed without judicial intervention. Overall, we analyzed a total sample of 3,387 articles. ${ }^{16}$

4. Coding Strategy. Although we coded at the level of the article, we treated each article as a collection of statements. All information, including quotations and paraphrased information, was coded if it spoke to the violence in Darfur. Often, a single article included several viewpoints, and in such cases all were coded. Yet coders did not attribute rare sentences or viewpoints that the author clearly and explicitly rejected.

Content analysis was conducted based on a coding scheme that comprised 179 variables of interest, organized into several major thematic categories (see appendix C). Given the detailed nature of the coding scheme, information on some variables was frequently missing. Yet missing information in this case is relevant in its own right. It tells us what aspects and details of the conflict are underexposed in journalistic depictions. The following themes encompassed the majority of variables:

- Degrees and types of acknowledgment of victimization and suffering, such as killings, rapes, displacements, or torture. We coded forms of suffering that were mentioned; numbers of affected Darfuris, where provided; and specific episodes that were displayed in detailed accounts. Such acknowledgment challenges states of denial, as explored by Stanley Cohen (200I).

- Actors involved. Here I am interested in the degree to which rebel forces, Janjawiid militias, and government officials are named as actors. The coding scheme further distinguished between references to individuals or collectivities and references to the rank of individuals within the hierarchy of their organizations.

- Perceived causes. Causes may point to distant events and conflicts, to the colonial past, to natural events such as the desertification of the Sahel zone and struggles over increasingly scarce resources, or to conscious decisions and strategies-such as the 
push toward Islamization, the neglect of the periphery, or the stirring up of racial resentment by central players on the ground and in high government offices.

- Frames or lenses through which the violence is interpreted. The coding scheme distinguishes between an insurgency frame, a civil war frame, a humanitarian emergency frame, a crime frame, and an aggressive-state frame that depicts the violence as disproportionately aggressive but not criminal. Frames can be diagnostic, identifying and attributing problems; prognostic, proposing solutions; or motivational, providing a rationale for engagement (Benford and Snow 2000). For example, while a civil war diagnostic frame identifies violence as a civil war, its prognostic equivalent may suggest negotiation as the appropriate response. The motivational frame provides a rationale or goal such as (in the civil war case) the establishment of peace. The coding scheme took account of these distinctions. Yet, one single article could invoke various frames. In fact, articles frequently included statements that fell in line with different frames in discussing violence in Darfur, for example, by characterizing it as both a civil war and a humanitarian emergency. Furthermore, articles at times included a statement that diagnosed the violence in a civil war frame while simultaneously offering a prognosis aligned with the humanitarian emergency frame. Such seeming contradictions typically result from journalists interviewing and citing, in the same article, different actors with distinct positions. In short, articles, with the exception of opinion pieces, are rarely characterized by a single frame.

- References to past atrocities. Producers of narratives often make use of bridging strategies. They seek to shed light on a new and yet unknown situation, here Darfur, by linking it to a past event whose meaning is well established. Coders were thus asked to code whether past atrocities were mentioned in association with Darfur. Building on our previous work (Savelsberg and King 20I I:60-64), the instrument further asked coders to document the use of different types of bridging: that the violence in Darfur was similar to a past atrocity (mimetic bridging); that the context of the violence was similar to that of past violence (contextual bridging); that this violence will have a similar outcome as a past atrocity (predictive bridging); or that Darfur differs from a past atrocity (bridging challenge). 
- Sources. When articles included quotations, sources were coded, especially organizational affiliations and, in some instances, names of individual informants.

5. Coders and Intercoder Reliability. Six coders, all PhD students in sociology, history, or political science, were chosen based on their language abilities (English, German, or French) and their familiarity with content analysis and social scientific methodology. Coders received one week of training and met weekly to discuss any questions or issues that arose during coding. In addition, coders coded three of the same articles (from different newspapers and time periods) each week in order to assess intercoder reliability; the principal investigator-author and Hollie Nyseth, lead research assistant, also periodically and randomly reviewed articles to assess each coder's work. Coding was done by hand, and each variable was assigned a quantitative code. Results were compiled into a dataset and analyzed using the stata statistical analysis program.

Intercoder reliability was higher for some variables than for others. It was almost perfect where no interpretive judgment was needed, for example, to determine whether or not killings were mentioned. Identifying frames in an article demanded more interpretive work by coders, and reliability was lower for those variables. Yet even the lowest Cohen's Kappa for variables used in the analyses on which this book is based demonstrated considerable agreement between coders. Intercoder reliability for all items present in this book was high (Cohen's [200I] Kappa ranging from 0.72 to I.00). ${ }^{17}$

Additional Sources of Data. Several additional data collection efforts supplemented the interview and content analysis work. They include analyses of multiple documents and press releases issued by the International Criminal Court on the situation in Sudan during the period under study; related documents of the foreign ministry websites of the countries included in this study; content analysis of I6I speeches, press releases, and reports from NGOs in the United States; and all press releases on Darfur from foreign ministries of seven of the countries under study.

\section{ROADMAP: DIRECTIONS FOR TRAVELING FROM HERE}

Guided by the questions and theoretical tools laid out thus far, and with a wealth of data at hand, I invite the reader to accompany me on a journey through the following chapters. In Part I of the book, 
"Justice versus Impunity," chapters I-3 explore the criminalization of the violence in Darfur in the context of the justice cascade. Chapter I focuses on the UN Security Council, the International Commission of Inquiry on Darfur, and-at the core of the justice field-the International Criminal Court. I examine conditions of the justice cascade, their application to the case of Darfur, and associated hopes invested in the cultural potential of judicial intervention. Hopes are confronted with constraints inherent in the institutional logic of criminal law. Chapter 2 examines INGOs dedicated to human rights issues by focusing on Amnesty International. I reconstruct Amnesty's representation of the violence in Darfur, adherence to rights discourses, and professional and national divergences. In chapter 3 , I discuss the role of the United States, a country that-despite its resistance against the ICC—embraced a criminalizing discourse vis-à-vis Sudan more than other countries. I pay particular attention to the Save Darfur Campaign, to government positions and US media narratives as they contrast with those in other Western countries, and finally to Amnesty USA in the context of the broader American Darfur movement.

A primary potential challenge to the notion of justice and the justice sector's representation of the mass violence in Darfur arises from the humanitarian aid field. I address this challenge in Part II, entitled "Aid versus Justice." Chapter 4 examines INGOs that have a humanitarian aid focus, specifically Doctors Without Borders (MSF), and the representation of Darfur generated in this field. We shall see that this representation differs distinctly from that which arises from the justice cascade. Chapter 5 investigates the "humanitarian complex" through the case of Ireland, a country with a memory of suffering and a foreign policy orientated toward humanitarian and development aid. Insights from interviews with Irish foreign policy makers and journalists are linked with an analysis of specific patterns of Irish media reporting.

Part III, "Peace versus Justice," engages the diplomatic field, a second potential challenger to the criminalizing narrative. Chapter 6 draws on interviews with Darfur and Sudan specialists in foreign ministries. I challenge depictions of foreign policy makers as actors guided by rational reasoning when they stay clear of genocide rhetoric so as to evade normative commitments to intervene, as suggested by Samantha Power (2002) for the United States and Karen Smith (2010) for Europe. Instead, dedramatizing rhetoric reflects the habitus of diplomats, cultivated in a field in which representatives of the perpetrating state are central players. Chapter 7 shows how the diplomatic field overlaps with 
national conditions characterized by varying social forces such as Sudanese lobbying, past colonial rule, foreign policy foci on humanitarianism or mediation, social movements, or collective memories. Each of these forces is more or less pronounced in each of the eight countries under analysis. Together they contribute to cross-national variation in the diplomatic field's representation of the mass violence in Darfur. Some countries, such as Switzerland, that invest prominently in mediation efforts to resolve foreign policy crises produce a representation of mass violence in Darfur that approximates the ideal typical diplomatic representation.

In part IV, entitled "Mediating Competing Representations: The Journalistic Field," I investigate the mediation of the justice narrative and its competitors from the humanitarian and diplomatic fields to a broad public in diverse countries. Chapter 8 explores the habitus of Africa correspondents, their career paths and the field in which they are embedded, the genres available to them, and the sources of information on which they depend as they report about Darfur. Chapter 9 traces the patterns of reporting based on the statistical analysis of the Darfur media data set. The chapter focuses especially on journalism's relationship with neighboring fields, including those discussed in the preceding chapters. How do political actors and market forces affect the intensity of reporting about Darfur? How do ICC interventions color the framing of the violence? What are the effects of the diplomatic and humanitarian fields? Chapter 9 also documents that the journalistic field is not homogeneous. Here, too, national distinctions color journalistic representations of the mass violence in Darfur as do a paper's ideological orientation and the gender of journalists.

Finally, chapter io summarizes lessons learned throughout the book and explores theoretical insights. How do field conditions shape representations of mass violence? Can those forces that drive the justice cascade successfully redefine responsible actors as criminal perpetrators? Do the humanitarian and diplomatic fields indeed hamper this effort? What is the role of the journalistic field in producing, reinforcing, and mediating to a world audience the competing definitions of mass violence? And how do global and national forces interact in the representation of mass violence? Answers to these questions matter as definitions of the situation become real in their consequences.

The postscript reflects on the most recent developments in Darfur and on international responses, especially among those institutions and fields that are the focus of this book. 